$\begin{array}{r}\text { ANGIELS } \\ \text { NEW PERSPETTUE5 } \\ \hline\end{array}$ ANELOPHONE WORLD

\section{Angles}

New Perspectives on the Anglophone World

9| 2019

Reinventing the Sea

\title{
A Sea of Violence and Love: Precarity, Eco-Fiction and the American Factor in Amitav Ghosh's The Hungry Tide
}

Maria-Sabina Draga Alexandru

\section{(2) OpenEdition}

Journals

Electronic version

URL: https://journals.openedition.org/angles/1175

DOI: $10.4000 /$ angles. 1175

ISSN: 2274-2042

Publisher

Société des Anglicistes de l'Enseignement Supérieur

\section{Electronic reference}

Maria-Sabina Draga Alexandru, "A Sea of Violence and Love: Precarity, Eco-Fiction and the American Factor in Amitav Ghosh's The Hungry Tide", Angles [Online], 9 | 2019, Online since 01 November 2019, connection on 06 June 2022. URL: http://journals.openedition.org/angles/1175 ; DOI: https://doi.org/ 10.4000/angles. 1175

This text was automatically generated on 6 June 2022.

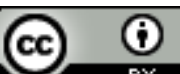

Angles est mise à disposition selon les termes de la Licence Creative Commons Attribution 4.0 International. 


\title{
A Sea of Violence and Love: Precarity, Eco-Fiction and the American Factor in Amitav Ghosh's The Hungry Tide
}

\author{
Maria-Sabina Draga Alexandru
}

\section{AUTHOR'S NOTE}

While writing this paper I benefited from the UEFISCDI-funded project PN-II-RU-TE 2014-4-0609, Representations of Violence in Contemporary American Popular Culture at the University of Bucharest and from an associate membership at the CEERES Center of the University of Chicago, which granted me access to the University of Chicago library, an invaluable source of bibliographical and background information.

1 Eco-fiction is environment-oriented fiction, usually looking at the increasingly fraught relationship between man and nature in the period of time that we call the Anthropocene. It focuses on the dangers coming from nature, which, in the current era of climate change, have continuously increased, going as far as imagining possible apocalyptic endings. Nature, placed under threat by human forces whose consumerism has become excessive, asserts its own self-defensive and even aggressive force. The human being, ambiguously positioned between the status of an ally and that of an enemy of nature, is confronted with more and more credible apocalyptic scenarios. Science and technology, celebrated as the glorious products of human reason, prove useless when confronted with the unleashed forces of nature. Whilst conflict is an important component of the current interest in ecology manifested in fiction, all this is part of a wider discussion about the increasingly blurred border between nature and culture. 
2 Reading almost any of Amitav Ghosh's recent writings from the perspective of the many connections that can be found between precarity and the sea opens up an interesting discussion about the author's long-term interest in engaging with the complex recent debate between nature and culture. His awareness of the unavoidable and multifaceted hybridization of the two in recent times points to the fact that much of his work could be read as a fictional enactment of a philosophy based around ambivalent concepts such as Donna Haraway's "natureculture". In The Companion Species Manifesto, Haraway builds an argument about the ethical necessity of granting humans and animals equal rights starting from showing how dogs are important as companions to humans:

The Companion Species Manifesto is, thus, about the implosion of nature and culture in the relentlessly historically specific, joint lives of dogs and people, who are bonded in significant otherness. Many are interpellated into that story, and the tale is instructive also for those who try to keep a hygienic distance. I want to convince my readers that inhabitants of technoculture become who we are in the symbiogenetic tissues of naturecultures, in story and in fact. (Haraway 2003: 16-7)

Bonds between humans and animals, of which the archetypally strongest is the one between humans and dogs, fluidify boundaries that, in the tradition of Enlightenment thought, used to be deemed unbreakable. Concepts such as Haraway's "natureculture" or Rosi Braidotti's "becoming animal" in Transpositions (2006) (which redefine the allegedly unquestionable rational superiority of the human through the permeability of the boundaries between it and other, presumably irrational, forms of life) emerge from theoretical explorations of the validity of the human/non-human divide that exposes its cultural constructedness. Otherness and othering, on which centuries of interhuman discrimination and oppression are based, are redefined across species boundaries. The non-human is brought as a kind of reconciling middle factor in the difficult opposition between the same and the other that has been at the centre of colonial conflicts. The intertwining between the natural and the cultural at a time when technological advancement and consumerism have led to an almost critical control of nature should actually be situated in a much wider context of blurring of all boundaries.

This focus on dynamic becoming, on the continuum of life, has been the preoccupation of postcolonial ecocriticism for some time (see Huggan and Tiffin 2010). The need for an ecological opening in postcolonial theory and criticism is considered by Graham Huggan and Helen Tiffin as a logical prolongation of centuries of colonial rule that, among other things, had, through exploitation, a significantly damaging effect upon the colonized countries. There is, in Huggan and Tiffin's opinion, a need for what Dominic Head calls the "fundamental social restructuring associated with 'deep ecology' over the 'provisional management strateg[ies]' of environmentalism" (Head 1999: 27, quoted in Huggan and Tiffin 2007: 5). Huggan and Tiffin go on to cite Lawrence Buell's (now classical) belief that "environmental crises and Western thought are intrinsically interwoven": "Western metaphysics and ethics need revision before we can address today's environmental problems" (Buell 1995: 2, quoted in Huggan and Tiffin 2007: 5).

5 In the climate of political and environmental damage in which we live, one cannot pretend not to notice that these two components can no longer be separated, as their histories have also long been intertwined. Indeed, recent human history has increasingly made its connection to climate change explicit, as Dipesh Chakrabarty 
points out in his article "The Climate of History" as he attempts to give "some responses to the contemporary crisis from a historian's point of view" (Chakrabarty 2009: 198). For him, history is living proof that nature and culture should go hand in hand: "natural history should not be separated from human history" (Chakrabarty 2009: 201), which is a prolongation of the New Historicist assumption that history is actually made not so much of what happens at the centre, but more of the marginal, apparently unimportant occurrences in human (and, we discover now, also nonhuman) lives.

6 Such histories written from the "environmental" margins of human culture are not free from the usual violence and precarity of history. Precarity as a given is also an increasingly present condition of today's life. A theoretical landmark on precarity, Judith Butler's Precarious Life (2004), written after September 11, theorizes the condition of life as permanently threatened by conflict that occasionally becomes acute. For Butler, precarity is related to war and, more generally, to the cataclysmic events that befall humans most often at the hands of other humans. Annamma Joy, Russell Belk and Rishi Bhardwaj comment on Butler's use of gender performativity in relation to precarity in direct connection to violence against women and to women's exile from power in India (Joy, Belk and Bhardwaj 2015: 1739). This is a line of inquiry that is particularly relevant to Nilima's social work to protect the disadvantaged women of Lusibari in Amitav Ghosh's The Hungry Tide (2004). This, however, will not constitute my main focus here. For Ghosh, precarity is related rather to weather and climate change and, more generally, to the violence with which nature, to whom humans have done violence, is now responding to humans. It is a different form of conflict, the outcome of a prolongation of the human into the non-human, on which Ghosh elaborates in a variety of ways in the novel, as he puts to work the rich symbolism of the dynamic land-sea symbiosis, always on the move and in a whole process of redefining its boundaries that one encounters in the Sundarbans.

7 Ghosh has had a lasting interest in asking questions about the ways in which nature is becoming more than just "the environment". His treatment of nature in his work (be it fictional or nonfictional) conceptualizes it as a real "other" in the broad sense in which Haraway talks about the understanding of otherness we have learned "from taking doghuman relationships seriously" (Haraway 2003: 3). Considering the disastrous human impact on nature in recent times, Ghosh's writing places an important emphasis on nature, in its fascinating fluidity. Nature takes part in the balance of a global world based on mutual respect and equality, which forms the basis of the author's own version of a postcolonial ecology.

Ghosh's recent essay book, The Great Derangement: Climate Change and the Unthinkable (2016) provides a literary reading of nature and climate change. Its very structure in three parts (Stories, History and Politics) betrays an intention to build an inductive argument starting from the narrative knowledge provided by concrete events, continuing with the wider framework of a domesticated history, in which nature plays an important part, and concluding with politics as a kind of theoretical musing on the importance of narratives and history. This book-length essay on ecology and its relevance to the human depicts a universe that throbs with life. In chapter 1, planets have lives of their own, betraying the never-ending cycles of death and rebirth of which the universe is made. Landscape is full of a life that makes it hard to grasp and 
map out: "This is a landscape so dynamic that its very changeability leads to innumerable moments of recognition" (Ghosh 2016: 6).

Ghosh traces a history of ecology, of which the human and the non-human are equal parts, which goes far back in time before the term was invented: "My ancestors were ecological refugees long before the term was invented" (Ghosh 2016: 3). Among other references to his novels, The Great Derangement abounds in references to The Hungry Tide. Talking about "the insistence with which the landscape of Bengal forces itself on the artists, writers and filmmakers of the region", Ghosh expands on "translating these perceptions into the medium of my imaginative life - into fiction, that is" and finds himself confronted with

challenges of a very different order from those that I had dealt with in my earlier work. Back then, those challenges seemed to be particular to the book I was writing, The Hungry Tide; but now, many years later, at a moment when the accelerating impacts of global warming have begun to threaten the very existence of low-lying areas like the Sundarbans, it seems to me that those problems have far wider implications. I have come to recognize that the challenges that climate change poses for the contemporary writer, although specific in some respects, are also products of something broader and older; that they derive ultimately from the grid of literary forms and conventions that came to shape the narrative imagination in precisely that period when the accumulation of carbon in the atmosphere was rewriting the destiny of the earth. (Ghosh 2016: 6-7)

Whereas he acknowledges that climate change is usually relegated to the realm of science fiction, Ghosh atypically uses it to read the present and even the past. He is interested in exploring the impact of climate change on the balance of the world, but also in relation to it, on the shape and manners of writing fiction.

The precarity of the planet is allegorically embodied by the fluid landscape of the Sundarbans. Since this is human-induced, the connections between climate change and culture are placed under direct scrutiny, since "the climate crisis is also a crisis of culture, and thus of the imagination" (Ghosh 2016: 9). An important part of the essay is dedicated to the idea of climate disasters such as tornadoes, with concrete reference to a highly impactful tornado in Delhi in 1978 (Ghosh 2016: 11-24). For Ghosh, the Sundarbans (a sea-land hybrid of precarity and uncertainty, "nothing like the forests that usually figure in literature" [Ghosh 2016: 28]) are a vantage point from which he looks at the world around to assess its own levels of precarity. Precarity is faced with what should be its opposite, predictability. In reality, the opposition between the two is weak, due to increasing levels of relativization in a world in which most things - the weather featuring high among them - are becoming increasingly hard to predict.

While discussing all these instances of precarity, Ghosh exposes the unreliability of presumably authoritative sources of information such as the National Research Council of the United States on predictability, with concrete reference to the radical unpredictability of Hurricane Sandy that hit the East Coast in 2012. In doing so, he implicitly questions America's position as a world superpower that is never wrong and goes as far as denying climate change (Ghosh 2016: 26). According to Ghosh, literature cannot assume "that nature was moderate and orderly" (22) as in the $19^{\text {th }}$ century because this is no longer the case. Consequently, there is a need for culture to emerge out of the traditional opposition with nature, and to take nature much more seriously (in tune with Haraway's above-mentioned concept of "natureculture"). All the more so as even the most allegedly unquestionable political power, the United States, becomes 
vulnerable when faced with the powerful unpredictability of natural disasters like Hurricane Sandy. This exposure of the vulnerability of America under the impact of a natural disaster that is not only unpredictable, but also extremely powerful, challenges the aesthetic boundaries of realism by being both "astoundingly real" and "urgently compelling" and also provides instances of "the uncanny intimacy of our relationship with the non-human" (Ghosh 2016: 33).

In The Hungry Tide, from the hauteur of her initial American superiority complex (which Kanai criticizes as soon as he meets her - "Does anybody have a choice when they are dealing with Americans these days?" [Ghosh 2004: 10]), Piya comes to question the American factor as presumably civilizing, and even to challenge American exceptionalism. The superiority complex that she borrows from American exceptionalism comes from an unquestionable assumption that she must know better since she comes from the United States, with its advanced level of science and technology, as well as a certain assumed confidence associated to American progress. All these, however, are contrasted to the locals' ancient repositories of a different kind of knowledge, transmitted across generations, whose depth makes Piya's science shy away: "Perhaps she was judging these men too harshly? Perhaps they really did possess great funds of local knowledge?" (Ghosh 2004: 32). At the end of the novel, it is thus true that her little GPS device is able to preserve all the water routes revealed to Piya by Fokir which are crucial to her research, but, at the same time, without the latter's knowledge, the GPS device might have proved useless.

In terms of Haraway's concept of "natureculture" (2003) which preceded the publication of The Hungry Tide (2004), Piya is culture, Fokir is nature, and Kanai is the translator/mediator between them. All three are key to the development of the plot and, symbolically, stand for three pillars of knowledge of sorts. One cannot help drawing a parallel with Salman Rushdie's short story "The Firebird's Nest", written for the June $23^{\text {rd }}$ and $30^{\text {th }} 1997$ issue of The New Yorker dedicated to the celebration of 50 years since India became independent from the British rule. The issue draws multiple parallels between the emergence of Indian literature as an alternative literature in English in its own right and the similar emergence of American literature 50 years after its own independence from Britain in 1776. In Rushdie's story, an unnamed American woman marries an Indian man from an impoverished noble background, significantly called Mr Maharaj, then moves to India with him and is received as a source of new energy in his land consumed by drought, where rain-bringing rituals have been performed in vain for ages. As their relationship fails, she leaves just as the drought is dramatically ended by a flood that claims the lives of many people, among which $\mathrm{Mr}$ Maharaj himself. We contemplate her flying over the ocean, pregnant, carrying the child of a hybrid couple that will change the global world we live in, as he will stand both for the traditions of India and the new energies of America.

The encounter between land and sea in the Sundarbans is violent, with the "hungry tide" always claiming its right over the terra ferma and with climate change performing even more violence on the land. The village of Lusibari, where most of the plot is set, lives a life of precarity par excellence, as it is literally situated in-between sea and land, an isolated island exposed to numberless perils - multiple forms of violence coming from the uncertainties of its condition and caused by both humans and nature:

Lusibari was about two kilometers long from end to end, and was shaped somewhat like a conch shell. It was the most southerly of the inhabited islands of the tide country - in the thirty miles of mangrove that separated it from the open sea, 
there was no other settlement to be found. Although there were many other islands nearby, Lusibari was cut off from these by four encircling rivers. Of these rivers, two were of medium size, while the third was so modest as to almost melt into the mud at low tide. But the pointed end of the island - the narrowest spiral of the conch - jutted into a river that was one of the mightiest in the tide country, the Raimangal. (Ghosh 2004: 36)

Perpetual violence threatens life on the island, trapped as it is between land and water, where the very existence of certain areas of land (and of the life on them) depends on the mercy of the ebbing and flowing waters: "But Kanai knew that once the tide turned everything would disappear. [...] Depending on the level of the tide, he remembered, the view was either exhilarating or terrifying" (Ghosh 2004: 36). Yet, as Nilima tells him, people come to populate this land of dreams that are more beautiful than the reality even from more secure parts of the Sundarbans, lured by the desire to own land, which was freely available to them (51). The value of land seems even higher as it has to be negotiated in a perpetual conflict with the water.

Many events in the novel happen on water which holds secrets about people who live and die in its territory. Nilima tells Kanai stories about the past he missed while he was away (Kusum died, leaving her son Fokir behind to be brought up by a relative). Nilima and Nirmal's own story sounds half submerged in legend, like the whole history of this place:

Nirmal and Nilima first came to Lusibari in search of a safe haven. This was in 1950 and they had been married less than a year. Nirmal was originally from Dhaka but had come to Calcutta as a student and then history interfered with their life: every major Asian uprising - the Vietnamese insurrection, the Malayan insurgency, the Red Flag Rebellion in Burma and much else. (Ghosh 2004: 76)

18 Faithful to her husband's memory, Nilima is still there, having founded a hospital in Lusibari and having espoused the fluid safety of this land of water, inhabited by fishermen who are at home even in the most entangled water labyrinths. Boatmen and fishermen such as Mej-da or Fokir hold the key to this fluid, floating universe, as they know its rules and rhythms and are prepared for its inconsistencies. Fishermen live precariously, in a complex symbiosis with nature, occasionally interrupted by guards who chase them when they fish in off-limits areas, ready to fine them unless bribed. The title of chapters, most of which focus on a single character (but also on "Crabs" and "Travels"), are like episodes in a collective history of the Sundarbans made up of converging individual human stories. These are, importantly, intertwined with those of nature and with the flashbacks of the past offered by Nirmal's notebook (which Kanai reads carefully and then reconstitutes from memory when the notebook is lost in the flood), and which, from a point on, regularly alternate with stories about the present.

Like these fishermen, Piya, the intruder who slowly comes to feel at home in this place where she doesn't even speak the language of the locals, also spends a lot of time on water, but her scrutiny is different from theirs - or at least so she thinks. Details are given about her research which almost develops a narrative of its own, revealing Ghosh's interest in the stories that can be told through every kind of language, including the language of science, as well as his own scientific preoccupations. Stories are of many kinds, revealing a faith in a narrative way of expressing knowledge about the world, as well as personal thoughts and feelings. Kanai declares his love to Piya in a letter, in which he tells her a story (which, he thinks, is a gift nobody else could have given her), whereas Fokir, a more elemental man who is also attracted to Piya, saves 
her life dramatically like an epic hero, sheltering her in the flood with his body, first alive, then lifeless, until she is rescued.

Piya goes through many stages in her understanding of this place. At first, she doesn't fit in at all. Not even her eating preferences coincide with the local customs, despite her Bengali origins, as they are slightly westernized and do not agree with Indian cuisine ("A Pilgrimage"). Yet, the Sundarbans, for all their looming dangers, are welcoming to her and offer her shelter, mainly through the protection offered by the two men, Kanai and Fokir. Among the many impending threats of this insecure territory, love can be of many types, but the one that dominates them and survives beyond death, leading to Piya's bold and innovative conservation project, is the attraction between the Indian-American marine biologist, and Fokir, the illiterate Bengali boatman. They stand for the nature/culture opposition (or, as they become a couple of sorts, for Haraway's "natureculture"), yet the implications of this opposition are not exactly the ones which we can immediately expect. Between the two knowledges the two of them represent, it is actually Fokir that proves superior in terms of understanding the depths of the world of the Sundarbans and of its dolphins, of their ecology and raison d'etre, even if Piya knows more about the dolphins' anatomy and scientifically-proven behaviors.

Ghosh's project, as expressed in his fiction and non-fiction books, seems to be to achieve equality among all living beings across all divides as the ultimate goal of postcolonialism, which is why non-human living beings play a crucial part in his fictional world. They are even invested with an agency which, were it to be recognized, would change the world for the better. The author thus reconsiders the function of postcolonialism (a formerly progressive discourse which is now considered somewhat dated, but which he thinks can be pushed to further, still profitable limits). In The Great Derangement, he asks a critical question:

What would have happened if decolonization had occurred earlier (after WWI)? Would the economies of mainland Asia have accelerated sooner? Did imperialism delay the onset of the climate crisis by retarding the expansion of Asian and African economies? (Ghosh 2016: 109)

As he worries about carbon dioxide emissions in the Sundarbans, Ghosh points out that imperialism was not the only obstacle in Asia's path to industrialization and demands for climate reparations in a complex activist manner. His critical activist thoughts are supported by his fiction (all the more powerful through the value of individual - even if fictional - agency). Climate change is the unintended consequence of the very existence of human beings as a species. The solution Ghosh proposes is a radical reconsideration of human moral principles. In Part III of The Great Derangement, for example, he discusses the ways in which climate change threatens freedom. Freedom has traditionally been defined in terms of human constraints, but now that non-human forces have arisen, how are we to rethink those conceptions of history and agency? How are Piya and Fokir to redefine their responsibility to the human species, as well as to the natural balance of the world of which they are both a part, but which Piya had left behind for a while in her desire to excel scientifically by belonging as fully as possible to the western world? As she redefines herself in her space of origin, it turns out that many answers she had been looking for in the West were back in the East, as revealed by her fieldwork in the Sundarbans, but also by the human encounters she experiences there, which reconnect her to the natural balance of the universe. 


\section{The Hungry Tide, in a chapter entitled "An Epiphany", Piya realizes the whole point of} her work as a field biologist:

She had never had high aspirations for herself as a scientist. Although she liked cetaceans and felt an affinity for them, she knew it was not just for the animals that she did what she did. As with many of her peers, she had been drawn to field biology [...] because it allowed her to be on her own, to have no fixed address, to be far from the familiar while still being part of a loyal, but loose-knit community. (Ghosh 2004: 126)

For Piya, being a cetologist and thus living "with no fixed address" is a way of testing the boundaries of her own freedom and, further, of her own beliefs. It is, ultimately, her way to find out a lot more about herself than about the world around her.

When she first appears in the novel, Piya is proud of her Americanness, which feels like an advantage over the people living in the tide land, with its aura of legend, but also its technological and even cultural backwardness. Like Mr Maharaj's American bride in Rushdie's story "The Firebird's Nest", whose role seems to be to bring fertility (in the shape of her American dollars) to India, Piya thinks she is there to save the eco-climate of the Sundarbans. She even tries (unsuccessfully) to disturb the ancient ritual order of the place in the chapter entitled "A Killing", when a tiger which had killed many humans and animals is caught and set on fire by the villagers (Ghosh 2004: 294). And yet, eventually, it is this microclimate that ends up saving her. As the plot advances, there are times when she even perceives her Americanness as a lack, as is the case when she confesses to Nilima that her parents never taught her Bengali because they were rather without roots themselves, and they wanted her to fit within American society. Things are further complicated by the fact that, as her parents stop talking to each other, she becomes an intermediary between them, a role which reveals a childhood trauma that brings tears to Nilima's eyes (Ghosh 2004: 250) and which Piya is able to overcome only in the Sundarbans. It is in the Sundarbans that she is about to lose her life twice, and it is twice that she is saved by Fokir, the boatman, the second time at the cost of his life. In The Great Derangement, Ghosh comments on this scene in The Hungry Tide as an example of the extent to which human life is overpowered by the forces of nature. However, even though the gigantic storm surge in the Sundarbans kills Fokir, he has managed to save Piya through the force of his attachment to her.

At the end, Piya learns something much more important about her own vulnerabilities as an American: the knowledge we need to keep the world going is much more complex than the world power struggles in which America takes the lead. Against the violence of nature and human lack of understanding, we need the loving lessons we learn from both people and nature to find out who we truly are. In the two books discussed in this contribution, Ghosh uses ecology as an overarching discourse meant to pass implicit judgment on the futility of all forms of human power, be they political or otherwise. 


\section{BIBLIOGRAPHY}

Braidotti, Rosi. Transpositions: On Nomadic Ethics. Cambridge \& Malden, MA: Polity, 2006.

Buell, Lawrence. The Environmental Imagination: Thoreau, Nature Writing, and the Formation of American Culture. Cambridge, MA: Harvard UP, 1995.

Butler, Judith. "Precarious Life, Vulnerability, and the Ethics of Cohabitation". The Journal of Speculative Philosophy 26(2) 2012: 134-151. DOI: 10.5325/jspecphil.26.2.0134

Butler, Judith. Precarious Life: The Powers of Mourning and Violence. London and New York: Verso, 2004.

Chakrabarty, Dipesh. "The Climate of History: Four Theses". Critical Inquiry 35(2) Winter 2009: 197-222. DOI: 10.1086/596640.

Chakrabarty, Dipesh. "Postcoloniality and the Artifice of History: Who Speaks for 'Indian' Pasts?" Representations, Special Issue: Imperial Fantasies and Postcolonial Histories 37 Winter 1992: 1-26. DOI: $10.2307 / 2928652$.

Dixon, Robert. “'Travelling in the West': The Writing of Amitav Ghosh.” In Tabish Khair (ed.), Amitav Ghosh: A Critical Companion. Delhi: Permanent Black, 2003. 9-35.

Ghosh, Amitav. The Hungry Tide. London: HarperCollins, 2004.

Ghosh, Amitav. The Great Derangement. Climate Change and the Unthinkable. Chicago: U of Chicago P, 2016.

Haraway, Donna. The Companion Species Manifesto. Chicago: U of Chicago P, 2003.

Head, Dominic. "The (im)possibility of ecocriticism". In R. Kerridge and N. Sammells (eds), Writing the Environment: Ecocriticism and Literature. London: Zed Books, 1999. 27-39.

Huggan, Graham and Helen Tiffin. Postcolonial Ecocriticism: Literature, Animals, Environment. London: Routledge, 2010.

Huggan, Graham and Helen Tiffin. “Green Postcolonialism”. Interventions 9(1) 2007: 1-11. DOI: $10.1080 / 13698010601173783$.

Joy, Annamma, Russell Belk and Rishi Bhardwaj. "Commentary. Judith Butler on performativity and precarity: exploratory thoughts on gender and violence in India". Journal of Marketing Management 31(15-16) 2015: 1739-1745. DOI: 10.1080/0267257X.2015.1076873.

Rushdie, Salman. “The Firebird's Nest”. The New Yorker, June 23 \& 30 1997: 122-7. https:// www.newyorker.com/magazine/1997/06/23/the-firebirds-nest

\section{ABSTRACTS}

This paper will interrogate a set of popular tropes and clichés that have become characteristic of the emerging genre of eco-fiction (eg. an impending threat such as an ecological disaster; endangered nature as a force in its own right which protects and threatens the human being; the uselessness of science and technology against the unleashed forces of nature) in a reading of Amitav Ghosh's 2004 novel The Hungry Tide. I will examine the novel's use of such tropes with hindsight, in the light of Ghosh's 2016 non-fiction book The Great Derangement: Climate Change and the Unthinkable, where the author's interest in ecology, global warming and the agency of fiction 
with respect to ensuing threats to human civilization becomes manifest. Using Graham Huggan and Helen Tiffin's concept of "green postcolonialism", I will argue that the two books share a deep concern with the ways in which the relationship between nature and culture, which has changed dramatically in the recent decades, mirrors a change in the relationship between the "West" and the "East". Thus, if colonialism functioned on the basis of an assumption of superiority with respect to non-European civilizations, it is now non-European forms of knowledge, formerly considered "primitive", that prevail over Western knowledge when it comes to facing nature's revolt against various kinds of prolonged human aggression.

Cet article interrogera un ensemble de tropes populaires et de clichés qui sont devenus caractéristiques du genre émergent de l'éco-fiction (dans lesquels on trouve les thèmes comme la menace imminente de catastrophe écologique, la nature en voie de disparition ou vue comme une force à part entière qui protège et menace l'être humain, ou encore où l'on voit l'inutilité de la science et de la technologie confrontés à une nature déchaînée). Nous proposons une lecture du roman d'Amitav Ghosh paru en 2004, Le pays des marées pour voir l'utilisation de ces tropes à la lumière du livre de non-fiction de Ghosh paru en 2016, The Great Derangement: Climate Change and the Unthinkable, où l'auteur manifeste clairement son intérêt pour l'écologie, le changement climatique et le pouvoir de la fiction face aux forces qui menacent la civilisation humaine. En utilisant le concept de "postcolonialisme vert» de Graham Huggan et Helen Tiffin, nous affirmons que les deux livres partagent l'idée que la relation entre la nature et la culture, qui a considérablement changé au cours des dernières décennies, reflète un changement dans les relations entre l'«Ouest» et l'«Est». Ainsi, si le colonialisme fonctionnait sur la base d'une supériorité supposée par rapport aux civilisations non-européennes, ce sont maintenant des formes de connaissance non-européennes, anciennement considérées comme "primitives ", qui prévalent sur la connaissance occidentale quand il s'agit de faire face à la révolte de la nature contre divers types d'agressions humaines prolongées.

\section{INDEX}

Mots-clés: facteur américain, éco-fiction, amour, précarité, mer, violence

Keywords: American factor, eco-fiction, love, precarity, sea, violence

\section{AUTHOR}

\section{MARIA-SABINA DRAGA ALEXANDRU}

Maria-Sabina Draga Alexandru is Associate Professor of American Studies at the University of Bucharest and, since 2015, an associate researcher at CEERES, the University of Chicago. Her research interests include: contemporary Indian fiction in English and its mythical rewritings, interactions between narrative and performance in contemporary global literatures in English, ethnic American literatures, minority cultures in the media, postcolonialism and postcommunism, gender studies. She has published articles in journals such as Comparative Literature Studies, The Journal of Commonwealth Literature, Perspectives, The European Journal of American Culture etc. She has authored and co-edited books, notably: The Postmodern Condition: Towards an Aesthetic of Cultural Identities (University of Bucharest Press, 2003); Identity Performance in Contemporary Non-WASP American Fiction (University of Bucharest Press, 2008); Between History and Personal Narrative: East-European Women's Stories of Transnational Relocation (co-edited; Vienna and Berlin: LIT Verlag, 2013); Performance and Performativity in Contemporary Indian Fiction in English (Leiden and Boston: Brill Rodopi, 2015). Contact: sabina.draga.alexandru[at]lls.unibuc.ro 